\title{
Is there any correlation between TNF-related apoptosis- inducing ligand (TRAIL) genetic variants and breast cancer?
}

Yemliha Yildiz, Ilhan Yaylım-Eraltan¹, Soykan Arikan² , H. Arzu Ergen¹ ${ }^{1}$ Seden Küçücük³ , Turgay Isbir

1Department of Molecular Medicine, Institute of Experimental Medicine, Istanbul University, Istanbul, Turkey

2Surgery Clinic, Istanbul Research and Teaching and Research Hospital, Istanbul, Turkey

3Institute of Oncology, Istanbul University, Istanbul, Turkey

${ }^{4}$ Yeditepe University, Medical Faculty Department of Medical Biology, Istanbul, Turkey

Submitted: 20 June 2010

Accepted: 25 August 2010

Arch Med Sci 2010; 6, 6: 932-936

DOI: 10.5114/aoms.2010.19304

Copyright (c) 2010 Termedia \& Banach

\section{Abstract}

Introduction: TNF-related apoptosis-inducing ligand (TRAIL) is a death ligand and also a member of the TNF superfamily. We aimed to investigate the possible relationship between TRAIL and breast cancer. Here, we report the results of the first association study on genetic variation in the TRAIL gene and its effect on breast cancer susceptibility and prognosis.

Material and methods: A C/T polymorphism at 1595 position in exon 5 of the TRAIL gene was genotyped in a Turkish breast cancer case-control population including 53 cases (mean age: $55.09 \pm 11.63$ years) and 57 controls (mean age: $57.17 \pm 17.48$ years) using polymerase chain reaction-restriction fragment length polymorphism (PCR-RFLP) analysis.

Results: There were no differences in the distribution of TRAIL genotypes and frequencies of the alleles in the breast cancer patients and controls. A heterozygous TRAIL CT polymorphism in exon 5 was present in $8.3 \%$ of tumour stage III-IV and $48.8 \%$ of stage I-II patients, and in $42.1 \%$ of controls. The reduced frequency of this genotype in patients who had advanced tumour stage was statistically significant $(p=0.017)$.

Conclusions: Our findings indicate that genetic variants of TRAIL at position 1595 in exon 5 might be associated with progression of breast cancer.

Key words: TRAIL, breast cancer, susceptibility, prognosis, polymorphism

\section{Introduction}

The contribution of genetic factors to the development of breast cancer, one of the most common human neoplasms, accounting for approximately one quarter of all cancers in females, has been verified by numerous genetic and epidemiological case-control studies [1]. Apoptosis, or programmed cell death, plays an important role in cell proliferation control throughout embryonic and adult life. The role of apoptosis in oncogenesis is currently being studied intensively in several cancers [2]. It is known that defects in apoptotic (programmed cell death) mechanisms play an important role in pathogenesis and progression of breast cancer. Some studies have reported that expression of multiple apoptosis-modulating proteins in breast cancer cell lines and primary tumours suggests complexity in the regulation of apoptosis in the neoplasms of mammary epithelial origin. But, relatively little is known about which apoptosis-regulating genes are expressed in tumours of mammary epithelial origin and the molecular mechanisms underlying these effects [3]. Tumour

\author{
Corresponding author: \\ Assoc. Prof. Ilhan Yaylım- \\ Eraltan \\ Department of Molecular \\ Medicine \\ Institute of Experimental \\ Medicine \\ Istanbul University \\ DETAE 34280 Çapa/Istanbul, \\ Turkey \\ Phone/fax: \\ +902126351959 \\ E-mail: \\ yaylimyaylim@yahoo.com
}


necrosis factor (TNF)-related apoptosis-inducing factor (TRAIL) is a death ligand, a member of the TNF/nerve growth factor superfamily, and preferentially induces apoptosis in tumour cells but not in normal cells. It is known that TRAIL selectively kills cancer cells without causing any harm to normal cells [4, 5]. However, a considerable proportion of human tumours (60\%) appear to be TRAIL resistant and the mechanism of TRAIL resistance is still unclear $[6,7]$. Five TRAIL receptors, which are called TRAIL-R1 or death receptor 4 (DR4), TRAIL-R2 or DR5, TRAIL-R3 or decoy receptor 1 (DcR1), TRAIL-R4 or DcR2, and osteoprotegerin (OPG), have been described [8]. It is known that only two of the TRAIL receptors, TRAIL-R1 and TRAIL-R2, contain functional death domains capable of inducing apoptosis [6]. When TRAIL interacts with one of these five receptors, it can induce or inhibit apoptosis, depending on which receptor is utilized [9-13]. TRAIL is located at chromosome 3q26. It is composed of five exons and encodes a 1.77-kb mRNA. Four single nucleotide polymorphisms (SNPs) in the 5'-regulatory region [14] and four SNPs in the 3'-untranslated region (3'UTR) $[15,16]$ of the TRAIL gene have been described. It has also been reported that there is a highly polymorphic region in the TRAIL promoter with four SNPs located in a 111 base pair (bp) spanning sequence between nucleotides 707 and 597 upstream of the transcriptional start site. However, it did not influence TRAIL expression in patients with multiple sclerosis [17]. On the basis of the mRNA sequence, three SNPs have been identified in the 3'UTR at nucleotides 1525, 1588, and 1595 of the TRAIL gene [16]. There have been no studies on the effect of TRAIL $1595 \mathrm{C} / \mathrm{T}$ polymorphism in human tumours. The aim of the present study was to analyse the relationships between TRAIL gene polymorphism in the 3'-untranslated region of exon 5 at position 1595 and disease susceptibility and prognostic implications in 66 Turkish patients with breast cancer.

\section{Material and methods}

\section{Study participants}

Fifty-three breast cancer patients (mean age $55.09 \pm 11.63$ years; age range $31-78$ years) and 57 healthy females (mean age $57.17 \pm 17.48$ years; age range 32-87 years) were included in the study. All subjects provided written informed consent before they participated in the study. Participants were selected from Istanbul Research and Education Hospital, Surgery Clinic. Questionnaires, medical records, and pathological reports were received to confirm the diagnosis and cancer status. The control subjects were randomly selected among volunteers and were not taking any regular medication at the time of the study. The samples were collected before any chemotherapeutic or radiation therapy treatment had been started. Blood samples were taken from patients who had pathological diagnosis and had not undergone blood transfusion. A standardized questionnaire was administered to collect data concerning age, family history of breast cancer, and family history of any kind of cancer for our breast patients from whom we obtained blood samples. Pathological staging information on all breast cancer diagnoses were confirmed by manual review of the pathology reports and clinical charts. Nodal status was categorized as no regional lymph nodes affected (NO) or at least one nodal metastasis. This study was approved by the Medical Ethics Committee of Istanbul Medical Faculty.

Isolation of DNA. Blood specimens were collected into tubes containing EDTA. DNA was isolated from white blood cells by sodium dodecyl sulphate lysis, proteinase $\mathrm{K}$ digestion, ammonium acetate extraction and ethanol precipitation [18].

Polymerase chain reaction (PCR) for TRAIL gene. For the TRAIL $1595 \mathrm{C} / T$ polymorphism forward primer 5'-TGA GCA CTA CAG CAA ACA TGA-3' and the reverse primer 5'-GCA CCA CTA AAA GAT CGC AGT-3' were used [19] at a concentration of $10 \mathrm{pmol} / \mu \mathrm{l}$ for each primer. The PCR reaction mixture contained $150 \mathrm{ng}$ DNA template, $1.5 \mathrm{mM} \mathrm{MgCl} 2,50 \mathrm{mM} \mathrm{KCl}$, $10 \mathrm{mM}$ Tris- $\mathrm{HCl}$ (pH 8.4), $200 \mu \mathrm{M}$ each of deoxynucleotide triphosphate (MBI Fermentas, Vilnius, Lithuania), and 2 units of Taq DNA polymerase (MBI Fermentas, Vilnius, Lithuania).

The DNA was denatured at $95^{\circ} \mathrm{C}$ for $5 \mathrm{~min}$, and temperature cycling was set at $94^{\circ} \mathrm{C}$ for $1 \mathrm{~min}, 56^{\circ} \mathrm{C}$ for $1 \mathrm{~min}$ and $72^{\circ} \mathrm{C}$ for $1 \mathrm{~min}$ for 30 cycles, followed by a final extension at $72^{\circ} \mathrm{C}$ for $10 \mathrm{~min}$. The 391 base pair PCR product was digested by Rsal (MBI Fermentas) at $37^{\circ} \mathrm{C}$ for 2.5 hours. After Rsal digestion of this PCR product, we detected two fragments having 59 and 332 bp (C allele) or three fragment having 59, 146, and 186 bp (T allele) (Figure 1). Digestion products were visualised under ultraviolet light and a photo was taken with a Polaroid camera. In the case of any doubt concerning the allele, the sample was analysed once again.

Statistical analysis. All statistical analyses were carried out using SPSS version 7.5 for Windows

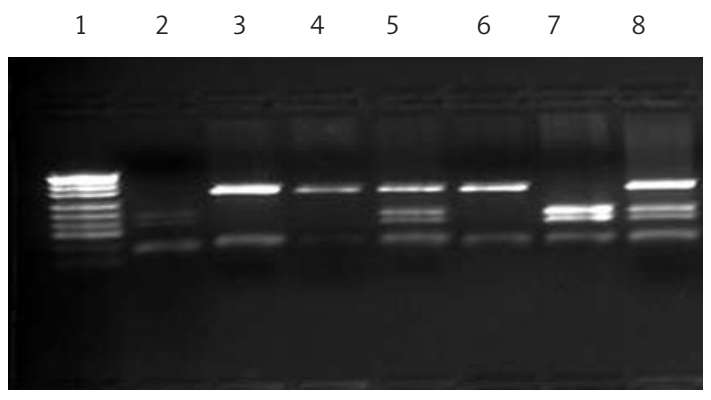

Figure 1. Direct visualization of PCR-RFLP typing pattern of TRAIL genotypes by ethidium bromide staining. A 391-base pair TRAIL 1595 C/T fragment was amplified, cleaved with Rsal, and electrophoresed on a 3\% agarose gel. Results from seven representative breast cancer patients are shown. Lane 1: pUC19/Msp1 marker; lane 2: TT homozygote; lane 3,4: CC homozygote; lane 5: CT heterozygotes; lane 6: CC homozygotes; lane 7: TT homozygotes; lane 8: CT heterozygotes 
Table I. Genotypes and allele frequencies for TRAIL $1595 \mathrm{C} / T$ in breast cancer patients and controls

\begin{tabular}{|lcccccc|}
\hline Genotype & $\begin{array}{c}\text { Patients, } \\
n=53\end{array}$ & $\%$ & $\begin{array}{c}\text { Controls, } \\
n=57\end{array}$ & $\%$ & OR (95\% Cl) & $P$ value \\
\hline CC & 26 & 49.1 & 28 & 49.1 & $0.999(0.682-1.462)$ & 0.994 \\
\hline CT & 21 & 39.6 & 24 & 42.1 & $0.941(0.600-1.477)$ & 0.791 \\
\hline TT & 6 & 11.3 & 5 & 8.8 & $1.291(0.418-3.981)$ & 0.656 \\
\hline Alleles & & & & & & - \\
\hline C & 73 & 68.9 & 80 & 70.2 & - & 0.83 \\
\hline T & 33 & 31.1 & 34 & 29.8 & - & \\
\hline
\end{tabular}

The $p$-value was obtained by $\chi^{2}$ test. \#Odds ratio for genotype was calculated as selected genotype vs. other genotypes. $O R$ indicates crude odds ratio

(SPSS Inc, Chicago, USA). Numeric values were analysed by Student's t-test. Differences in characteristics between breast cancer patients and controls, as well as disparities in genotype and allele frequencies, were assessed with the chi-square test. Odds ratios (ORs) and 95\% confidence intervals $(95 \% \mathrm{Cl})$ were calculated to estimate the risk for breast cancer. P-values less than 0.05 were considered statistically significant.

\section{Results}

In the present study, we determined TRAIL 1595 $\mathrm{C} / \mathrm{T}$ polymorphism in 53 breast cancer patients and 57 controls. Genotypes and allele frequencies for TRAIL $1595 \mathrm{C} / \mathrm{T}$ in breast cancer patients and controls are listed in Table I. With the use of the $\chi^{2}$ test, we found that differences in TRAIL $1595 \mathrm{C} / \mathrm{T}$ genotype and allele frequencies between breast cancer patients and controls were not statistically significant ( $p=0.896, p=0.830$, respectively). Distribution of TRAIL 1595 C/T genotypes according to clinical parameters and tumour characteristics of breast cancer patients are summarized in Table II. Patients with T3/T4 stage breast carcinoma showed a lower prevalence of TRAIL CT (8.3\%) genotype when compared to patients with $\mathrm{T} 1 / \mathrm{T} 2$ stage (48.8\%) breast cancer ( $p=0.017$; OR: 0.171 $95 \% \mathrm{Cl} 0.025-1.145)$. Among breast cancer patients, there was no significant association between the TRAIL 1595 C/T genotypes and age, family history of breast cancer, oestrogen receptor, or progesterone receptor. The genotype distributions of our patients and controls were in line with the Hardy-Weinberg equilibrium ( $p=0.580$ for patients, $p=0.960$ for controls).

\section{Discussion}

TRAIL selectively killed cancer cells without causing any harm to normal cells [5]. TRAIL can induce apoptosis in a broad range of human cancer cell lines including breast cancer cell lines [20, 21]. SNPs present along the TRAIL gene have been extensively studied in multiple sclerosis $[17,19]$. However, similar studies in cancer are lacking. An important gene polymorphism in TRAIL, reported by Gray et al. [16], has been identified in the 3'UTR at nucleotide 1595. The frequency of $\mathrm{C}$ allele at position 1595 for Caucasians and American Africans was 0.712 and 0.842, respectively. Kikuchi et al. [19] reported an association between the TRAIL $1595 \mathrm{C} / \mathrm{T}$ gene polymorphism and multiple sclerosis susceptibility in Japanese patients, and they also reported that the frequency of the $C$ allele was 0.592 in a Japanese population. In our study the frequency of the C allele at position 1595 was 0.702 in Turkish women. This was similar to Gray's findings [16]. The present study is the first preliminary report showing a relationship between breast cancer and TRAIL 1595 C/T gene polymorphism. In our study, we did not find any significant difference in the genotype distribution between patients and controls. In 2009, it was reported that TRAIL TT genotype was associated with a lower risk of fatty liver diseases (FLD) and a less severe form of steatosis in non-alcoholic fatty liver disease (NAFLD) patients in a Chinese population [22]. Yan et al. [22] found that NAFLD and AFLD patients also show significantly lower frequencies of 1595 TT genotype than healthy controls not abusing alcohol. They also measured soluble TRAIL (sTRAIL) levels in NAFLD and healthy subjects. They showed that Chinese individuals with TT genotype of TRAIL at 1595 position in 3'UTR have a lower susceptibility to FLD, and STRAIL concentrations in non-alcoholic FLD (NAFLD) patients were significantly higher than those of controls. They hypothesized that TRAIL gene polymorphism at this position might affect TRAIL's function in lipid metabolism [22]. Ganten et al. [23] determined the expression pattern of all surface-bound TRAIL receptors and their prognostic clinical value. They suggested that TRAIL receptor expression profile may aid in defining which breast cancer patients have a higher risk of lymph node metastasis and worse overall survival. It has been suggested that 
Table II. Distribution of TRAIL 1595 C/T genotypes according to clinical parameters and tumour characteristics of breast cancer patients

\begin{tabular}{|c|c|c|c|c|c|}
\hline & $N$ & $\%$ & CC (\%) & $\mathrm{CT}(\%)$ & $\Pi(\%)$ \\
\hline Age $\leq 45$ years & 12 & 22.6 & $4(33.3)$ & $7(58.3)$ & $1(8.3)$ \\
\hline Age $>45$ years & 41 & 77.4 & $22(53.7)$ & $14(34.1)$ & $5(12.2)$ \\
\hline \multicolumn{6}{|c|}{ Family history of breast cancer } \\
\hline Yes & 12 & 22.6 & $8(66.7)$ & $3(25)$ & $1(8.3)$ \\
\hline No & 41 & 77.4 & $18(43.9)$ & $18(43.9)$ & $5(12.2)$ \\
\hline \multicolumn{6}{|c|}{ Tumour $(\mathrm{T})$ stage } \\
\hline $\mathrm{T} 1$ & 14 & 26.4 & $7(50)$ & $6(42.9)$ & $1(7.1)$ \\
\hline $\mathrm{T} 2$ & 25 & 47.2 & $11(44)$ & $13(52)$ & $1(4)$ \\
\hline T3 & 10 & 18.9 & $5(50)$ & $2(20)$ & $3(30)$ \\
\hline T4 & 4 & 7.5 & $3(75)$ & $0(0)$ & $1(25)$ \\
\hline \multicolumn{6}{|c|}{ Lymph node status } \\
\hline NO & 14 & 26.4 & $7(50)$ & $6(42.9)$ & $1(7.1)$ \\
\hline $\mathrm{N} 1$ & 23 & 43.4 & $12(52.2)$ & $9(39.1)$ & $2(8.7)$ \\
\hline N2 & 13 & 24.5 & $6(46.2)$ & $5(38.5)$ & $2(15.4)$ \\
\hline N3 & 3 & 5.7 & $1(33.39)$ & $1(33.3)$ & $1(33.3)$ \\
\hline \multicolumn{6}{|c|}{ Distant metastasis } \\
\hline$(+)$ & 3 & 5.7 & $2(66.7)$ & $1(33.3)$ & - \\
\hline$(-)$ & 50 & 94.3 & $24(48)$ & $20(40)$ & $6(12)$ \\
\hline \multicolumn{6}{|c|}{ Oestrogen receptor } \\
\hline$(-)$ & 6 & 13.0 & $4(66.7)$ & $2(33.3)$ & - \\
\hline$(+)$ & 40 & 87.0 & $18(45)$ & $17(42.5)$ & $5(12.5)$ \\
\hline \multicolumn{6}{|c|}{ Progesterone receptor } \\
\hline$(-)$ & 7 & 15.2 & $4(57.1)$ & $3(42.9)$ & - \\
\hline$(+)$ & 39 & 84.8 & $18(46.2)$ & $16(41)$ & $5(12.8)$ \\
\hline
\end{tabular}

TRAIL also induces apoptosis in a variety of tumour cell types and suppresses the growth of colon and breast xenografts $[24,25]$. Preclinical testing of TRAIL in combination with conventional chemotherapeutic agents has demonstrated significant inhibition of tumour growth in a prostate cancer in vivo model [26]. Recently, Pal et al. [27] have reported that a promoter SNP of TRAIL functionally modulates the gene expression, and they advise considering the -716 TRAIL SNP status in patients undergoing TRAIL therapy. They showed that high TRAIL expressing individuals with -716 CC genotype are at a greater risk of developing tumour, which can be inferred from our observation of the predominance of the major genotype, CC, in the initial stages of breast cancer, ER/PR positive cases and small tumour size [27].

The major finding of the present study was that in breast cancer patients who have TRAIL CT genotype at position 1595 in 3'UTR, the tumour was in a non-advanced stage. At present, the influence of TRAIL gene polymorphisms on the functions of the TRAIL protein and on its involvement in the development and progression of breast cancer is still unclear. It has been suggested that complex and heterogeneous genetic alterations are involved in the aetiology of breast tumourigenesis. Analysis of multiple signalling pathways would be more informative and useful in both diagnosis and prognosis of breast tumours [28]. We evaluated, for the first time, the role of the TRAIL polymorphism at position 1595 in 3'UTR in breast cancer risk and progression by genotyping 53 cases and 57 healthy controls drawn from the Turkish population. Additional studies are needed to assess the role of TRAIL polymorphism in the risk and progression of breast cancer.

\section{Acknowledgements}

This study was supported by a grant from Istanbul University, Research Foundation (project number: 1715), Turkey. We are also grateful to the cancer epidemiologist Dr. Hakan Camlica for support and correction of statistical analysis. 


\section{References}

1. Otterbach F, Callies R, Frey UH, et al. The T393C polymorphism in the gene GNAS1 of $G$ protein is associated with survival of patients with invasive breast carcinoma. Breast Cancer Res Treat 2007; 105: 311-7.

2. Johnstone RW, Ruefli AA, Lowe SW. Apoptosis: a link between cancer genetics and chemotherapy. Cell 2002; 108: $153-64$

3. Zapata JM, Krajewska M, Krajewski S, et al. Expression of multiple apoptosis-regulatory genes in human breast cancer cell lines and primary tumors Breast Cancer Research and Treatment 1998; 47: 129-40.

4. Wiley SR, Schooley K, Smolak PJ, et al. Identification and characterization of a new member of the TNF family that induces apoptosis. Immunity 1995; 3: 673-82.

5. Nagane M, Huang HJ, Cavenee WK. The potential of TRAIL for cancer chemotherapy. Apoptosis 2001; 6: 191-7.

6. Griffith TS, Chin WA, Jackson GC, Lynch DH, Kubin MZ. Intracellular regulation of TRAIL-induced apoptosis in human melanoma cells. J Immunol 1998; 161: 2833-40.

7. Nesterov A, Lu X, Johnson M, Miller GJ, Ivashchenko Y, Kraft AS. Elevated AKT activity protects the prostate cancer cell line LNCaP from TRAIL-induced apoptosis. J Biol Chem 2001; 276: 10767-74.

8. Golstein P. Cell death: TRAIL and its receptors. Curr Biol 1997; 7: R750-3.

9. MacFarlane M, Ahmad M, Srinivasula SM, FernandesAlnemri T, Cohen GM, Alnemri ES. Indentification and molecular cloning of two novel receptors for the cytotoxic ligand TRAIL. J Biol Chem 1997; 272: 25417-20.

10. Sheridan JP, Marsters SA, Pitti RM, et al. Control of TRAIL induced apoptosis by a family of signaling and decoy receptors. Science 1997; 277: 818-21.

11. Degli-Esposti MA, Smolak PJ, Walczak H, et al. Cloning and characterization of TRAIL-R3, a novel member of the emerging TRAIL receptor family. J Exp Med 1997; 186: 1165-70.

12. Marsters SA, Sheridan JP, Pitti RM, et al. A novel receptor for Apo2L/TRAIL contains a truncated death domain. Curr Biol 1997; 7: 1003-6.

13. Pan G, Ni J, Yu G, Wei YF, Dixit VM. TRUNDD, a new member of the TRAIL receptor family that antagonizes TRAIL signalling. FEBS Lett 1998; 424: 41-5.

14. Wang Q, Ji Y, Wang X, Evers BM. (2000) Isolation and molecular characterization of the 5 '-upstream region of the human TRAIL gene. Biochem Biophys Res Commun 2000; 276: 466-71.

15. Unoki M, Furuta S, Onouchi Y, et al. Association studies of 33 single nucleotide polymorphisms (SNPs) in 29 candidate genes for bronchial asthma: positive association a T924C polymorphism in the thromboxane $A 2$ receptor gene. Hum Genet 2000; 106: 440-6.

16. Gray HL, Sorensen EL, Hunt JS, Ober C. Three polymorphisms in the $3^{\prime}$ UTR of the TRAIL (TNF-related apoptosis-inducing ligand) gene. Genes Immun 2001; 2: 469-70.

17. Weber A, Wandinger KP, Mueller W, et al. Identification and functional characterization of a highly polymorphic rgion in the human TRAIL promoter in multiple sclerosis. J Neuroimmunol 2004; 149: 195-201.

18. Miller SA, Dykes DD, Polesky HF. Simple salting out procedure for extracting DNA from human nucleated cells. Nucleic Acids Res 1988; 16: 1215.

19. Kikuchi S, Miyagishi R, Fukazawa T, Yabe I, Miyazaki Y, Sasaki H. TNF-related apoptosis inducing ligand (TRAIL) gene polymorphism in Japanese patients with multiple sclerosis. J Neuroimmunol 2005; 167: 170-4.
20. Keane MM, Ettenberg SA, Nau MM, Russell EK, Lipkowitz S. Chemotherapy augments TRAILinduced apoptosis in breast cell lines. Cancer Res 1999; 59: 734-41.

21. Ashkenazi A, Holland P, Eckhardt SG. Ligand-based targeting of apoptosis in cancer: the potential of recombinant human apoptosis ligand 2/tumor necrosis factor-related apoptosis-inducing ligand (rhApo2L/TRAIL). J Clin Oncol 2008; 26: 3621-30.

22. Yan X, Xu L, Qi J, et al. sTRAIL levels and TRAIL gene polymorphisms in Chinese patients with fatty liver disease. Immunogenetics 2009; 61: 551-6

23. Ganten TM, Sykora J, Koschny R, et al. Prognostic significance of tumour necrosis factor-related apoptosisinducing ligand (TRAIL) receptor expression in patients with breast cancer. J Mol Med 2009; 87: 995-1007.

24. Tolcher AW. Regulators of apoptosis as anticancer targets. Hematol Oncol Clin North Am 2002; 16: 1255-67.

25. Ferreira CG, Epping M, Kruyt FA, et al. Apoptosis: target of cancer therapy. Clin Cancer Res 2002; 8: 2024-34.

26. El-Zawahry AM, McKillop J, Voelkel-Johnson C. Doxorubicin increases the effectiveness of Apo2L/TRAIL for tumor growth inhibition of prostate cancer xenografts. BMC Cancer 2005; 5: 2.

27. Pal R, Gochhait S, Chattopadhyay S, et al. Functional implication of TRAIL -716 C/T promoter polymorphism on its in vitro and in vivo expression and the susceptibility to sporadic breast tumor. Breast Cancer Res Treat 2010; May 5. [Epub ahead of print].

28. Vinothini G, Letchoumy PV, Prathiba D, Nagini S. Immunohistochemical analysis of biomarkers in patients with adenocarcinoma of the breast: correlation with menopausal status and histological grade. Arch Med Sci 2008; 4: 129-39. 